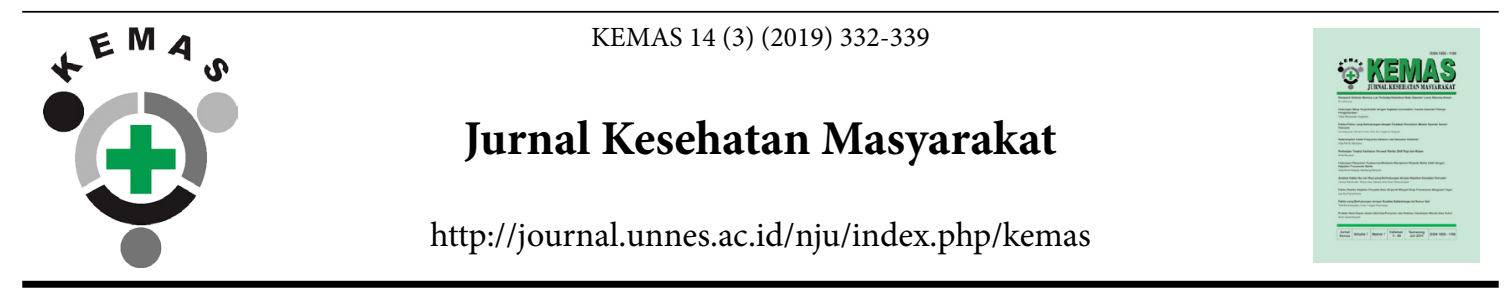

\title{
Risk Factors for Malaria in Pregnant Women
}

\author{
Sutarto $^{1 凶}{ }^{\bowtie}$ Dyah Wulan S.R. Wardani ${ }^{1}$, Rasmi Zakiah Oktarlina ${ }^{2}$, Sri Aryanti ${ }^{3}$, Reni Indriyani ${ }^{4}$ \\ ${ }^{1}$ Departemen of Community Medicine, Faculty of Medicine, University of Lampung, Indonesia \\ ${ }^{2}$ Department of Pharmacoloy, Faculty of Medicine, University of Lampung, Indonesia \\ ${ }^{3}$ Department Health of Lampung Province, Indonesia \\ ${ }^{4}$ Department of Nutritionis, Tanjungkarang, Indonesia
}

\begin{tabular}{l} 
Article Info \\
\hline Article History: \\
Submitted February 2018 \\
Accepted May 2018 \\
Published March 2019 \\
\hline Keywords: \\
Pravalence rate, Malaria, \\
risk factor, Pregnant Women \\
\hline DOI \\
https://doi.org/10.15294/ \\
kemas.v14i3.13443
\end{tabular}

\begin{abstract}
Malaria is a major worldwide contagious disease, including Indonesia, and is an important public health issue. Prevalence of malaria among pregnant women and its risk factors in Pesawaran, Lampung Province are currently unknown. This study was a crosssectional study using rapid survey method. Data was analyzed with chi square and logistic regression. Malaria prevalence was 47.6 per mile, spread over 5 out of 11 subdistricts. One important information was the discovery of pregnant women with malaria in non-endemic districts. The result of bivariate analysis proved a relationship between knowledge and malaria with p-value 0.007 and Odds Ratio (OR) 10. Maternal behavior had p-value of 0.009, OR 9, while usage of mosquito nets had p-value of 0.01 , OR 5. The multivariate analysis model formula found was $\mathrm{Y}$ (pregnant woman with malaria) $=$ $-7.546+2.353$ (knowledge) +2.270 (usage of mosquito net) +2.250 (house condition), and pregnant woman probability of malaria $33.9 \%$. Prevention efforts should be done through strengthening of integrated maternal class groups into malaria programs in all areas.
\end{abstract}

\section{Introduction}

Malaria is one of the most contagious diseases that remains a public health problem worldwide, including Indonesia. This disease increases mortality rate of infants, toddlers and pregnant women. Until December 2015, the number of region that reached the acceleration stage was 45 districts, intensification stage was 90 districts, and pre-elimination stage was 379 districts. Of the 379 regencies/cities that existed at the pre-elimination stage, 232 districts have been declared elimination or free of local transmission. This result had exceeded the target Rencana Pembangunan Jangka Menengah Nasional (RPJMN) 2015 programme, which was 225 districts reaching malaria elimination
(Kementerian Kesehatan RI, 2016).

Malaria is an important public health problem and affected almost half of the world's population. This condition is associated with high morbidity and mortality and when it comes to pregnant women, also adversely affect the mother and her fetus. Malaria in pregnant women is associated with a higher risk of anemia, low birth weight (LBW), premature birth and perinatal death. All of these conditions contribute to high maternal and infant mortality, especially in malaria endemic areas. In addition, fetuses exposed to malaria parasites may develop congenital infections or modified immune system against malaria which would affect the immune response of

\footnotetext{
Correspondence Address:

Departemen of Community Medicine, Faculty of Medicine University of Lampung,

C Building 3th Floor Kampus Hijau Unila Bandar Lampung, Indonesia.

Email : sutartoabbastayeb11@gmail.com
} 
infants to malaria in the first 1-2 years of life (Briand et al., 2016).

This condition is exacerbated by the spread of $P$. falciparum with chloroquine resistance $(\mathrm{Cq})$ and sulfadoxine-pyrimethamine and $P$. vivax against chloroquine in malaria endemic areas. This is a serious challenge to the effectiveness of malaria prevention programs in pregnancy (Karyana et al., 2008).

Pregnancy will increase the severity of malaria disease, and malaria will adversely affect pregnancy, resulting in maternal and fetal complications. Malaria infection in pregnancy is very harmful to the mother and her fetus because it increases maternal and fetal morbidity and mortality. Mothers with malaria may develop anemia, cerebral malaria, pulmonary edema, kidney failure and even death. In the fetus, malaria can cause abortion, premature labor, low birth weight (LBW), and fetal death. Pregnant women are prone to malaria due to changes in cellular and humoral immunity during pregnancy, which could be caused by increased cortisol level during pregnancy (Rusjdi, 2012).

In Lampung Province, there were 4 districts with API (Annual Parasite Insidence) in moderate category such as Kabupaten Pesawaran (6.36 per mile), Pesisir Barat (3.47 per mile) and Kota Bandar Lampung (0.58 per mile) and Lampung Selatan (0.23 per mile) (Kementerian Kesehatan RI, 2016).

The prevalence of malaria cases among pregnant women and how the control malaria in pregnant women in Lampung Province is unknown. This study chose Kabupaten Pesawaran for rapid survey to determine the prevalence of malaria among pregnant women and malaria risk factors for optimal control and prevention.

The World Health Organization (WHO) had developed a quick and inexpensive survey technique to see the extent of health issues. This survey technique was known as the Rapid Survey Method. Rapid Survey Method is used to investigate health problems.

The formulation of the problem in this study was unknown prevalence of malaria among pregnant women and methods to control malaria risk factor among pregnant mother in Kabupaten Pesawarant. General objective of this reseaech was to investigate malaria prevalence among pregnant mother, malaria risk factor and efforts to control malaria risk factor in Kabupaten Pesawaran, Provinsi Lampung, Indonesia.

\section{Method}

This study is non experimental, cross sectional study using rapid survey method. Sampling was done in 2 stages. First, we used cluster sampling and then determined the respondents from each cluster. The study was conducted in Kabupaten Pesawaran for 4 months in 2017 . There were 8,821 pregnant women in the working area of Kabupaten Pesawaran Regency spread over 144 villages in 11 districts. The sample was then selected by mapping the proportion of target pregnant women according to the village area at the cluster, with the number of villages per sub-district based on the proportion of pregnant women. The first stage of selecting clusters was taken randomly (30 villages), and then in the second stage, a number of respondents were taken from each village. The number of respondents per village was 7 people, so the number of respondents was 210 people (30 villages $\mathrm{x} 7$ people). Primary and secondary data were collected. Primary data was collected by trained enumerators through malaria examination using rapid diagnostic test (RDT) to determine the status of malaria disease in pregnant women, as the dependent variable. The other primary data was malaria risk factors through interview with structured questionnaires on each respondent pertaining to knowledge, behavior, usage of mosquito net and house condition and its environment, as independent variables. Secondary data was taken from related institutions, namely Pesawaran Subdistrict Health Office, Puskesmas Induk (Main Community Primary Health Care Center) in sub-district (kecamatan) and village midwife. Independent and dependent variables were analyzed using bivariate test with chi square and multivariate analysis with logistic regression method, and selection of candidate models with p-value limits below 0.26 other factors. Bivariate test was used to prove the hypothesis of the relationship between independent and dependent variable without considering other factors. Furthermore, multivariate test was used 
to make a model of malaria incidence among pregnant women related to 4 independent variables. This study has been approved for ethical clearance at August 16 $6^{\text {th }}, 2017$ with clearance number No.3239 / UN26.8 / DL / 2017.

\section{Results and Discussion}

Research was conducted in all subdistricts of Pesawaran District to investigate the prevalence and risk factors of malaria disease in pregnant women, during September - October 2017 and found in 10 people out of 210 pregnant women examined. From this research, it is known that malaria prevalence was 4.76 per 100 pregnant women (47.6 per mile) spread in 5 sub-districts from 11 districts. One important information is the discovery of maternal pregnant women in Negeri Katon sub-district, because there was no malaria incidence among pregnant women in the last 5 years with prevalence 35.71 per mile and the highest prevalence of malaria was in Punduh Pedada sub-district (428.57 per mile).

This research found pregnant women with malaria in 5 sub-districts, out of which 4 sub-districts were endemic for malaria and 1 sub-district was non-endemic (Negri Katon subdistrict). This situation indicated that there was transmission of malaria out of endemic areas, which deserves more attention from the local government of Pesawaran District. Malaria prevalence was higher compared to data reported to Community Health Centers (Puskesmas) at Pesawaran District in the last 3 years. This situation provides information for related institutions both Health Office of Pesawaran District and community health centers, intensive activities in all endemic subdistricts (Padang Cermin, Marga Punduh, Punduh Pedada and Teluk Pandan). This intervention is a malaria integrated activity with the services for pregnant mothers and immunization carried out through basic primary immunization services at basic health care facilities (community health centers, midwives, physicians, clinics and other health services both government and private).

Malaria in pregnant women will affect her pregnancy and cause maternal and fetal complications. Mothers with malaria may develop anemia, cerebral malaria, pulmonary edema, kidney failure and even death. In the fetus, it causes abortion, premature labor, low birth weight (LBW), and fetal death. Pregnant women are prone to malaria due to changes in cellular and humoral immunity during pregnancy, which could be caused by increased cortisol level during pregnancy (Muktar, 2007).

Malaria risk factors observed in this study were risk factors that exist around pregnant women such as knowledge of malaria among pregnant women, malaria prevention behaviors, the usage of mosquito nets and housing condition.

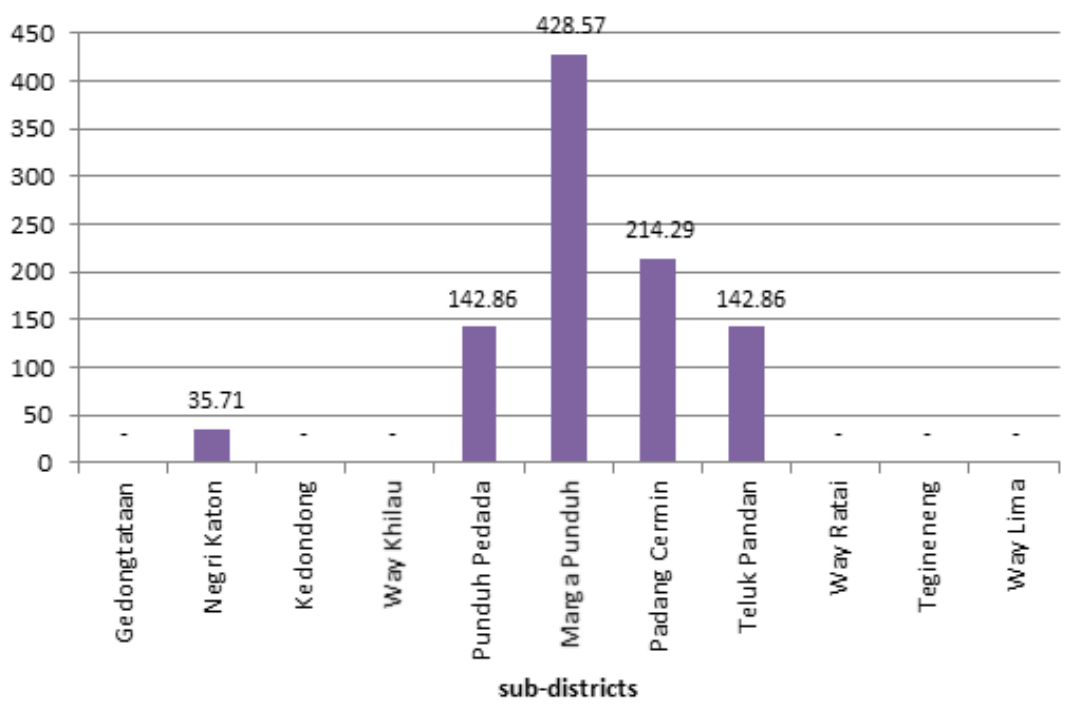

Figure 1. Malaria Rate Pevalence Pregnant Women permil Pregnant Women 


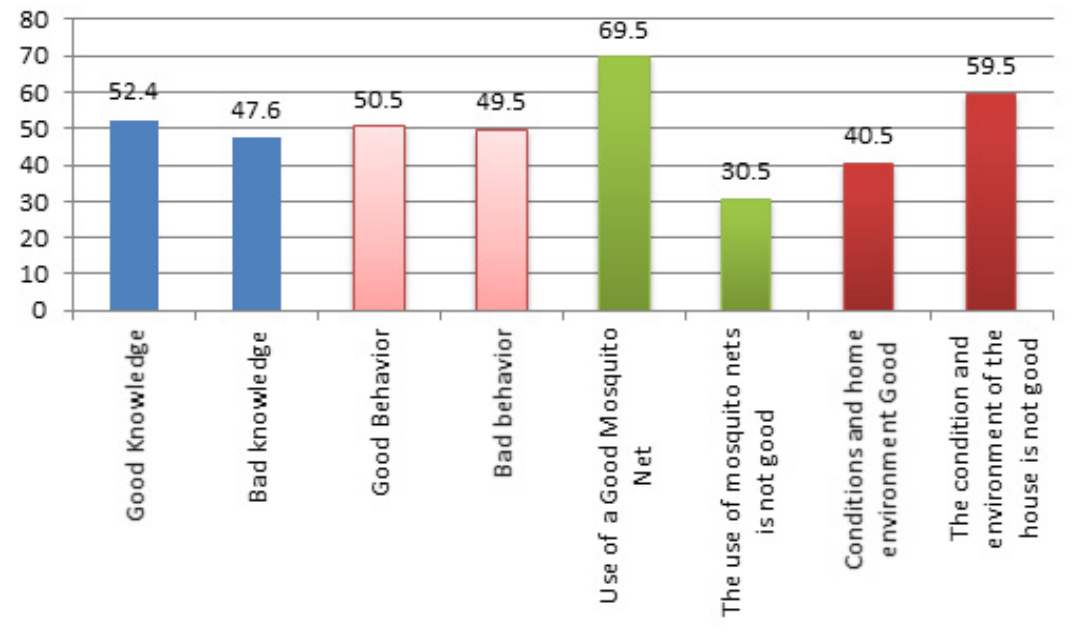

Figure 2. Distribution of Risk Factors Malaria Disease (\%)

The percentage of malaria risk factors was generally the same proportion between good and bad category, except for the risk factor of using mosquito net with "good" category (69.5\%) was more than "bad" category (30.5\%), which means people in Pesawaran District had "good" behavior in usage of mosquito nets to prevent malaria in pregnant women.

The use of mosquito net is a behavior to protect pregnant women Anopheles mosquitoes' bites. The study showed that pregnant women in Pesawaran District used mosquito net sufficiently well. WHO Regional of Africa recommends malaria control strategies among pregnant women in the form of use of insecticide-treated mosquito nets and effective management of malaria cases (Muktar, 2007).

The results of this study was analyzed further using bivariate and multivariate test. Bivariate analysis proved that there is enough evidence of risk factors studied in relation to the incidence of maternal malaria disease, except for house condition and environmental risk factors. The result of statistical test of risk factor and malaria incidence shows that 4 risk factors were closely related to malaria incidence, except house condition and environment. Therefore, prevention efforts at the household level have a good impact, by preventing and strengthening maternal groups integrated in malaria programs in all areas, especially in endemic areas, knowledge provision could change the behavior of both prevention on personal, and prevention in surrounding environment.
Rigorous monitoring/surveillance by local Community Health Centers for pregnant women with malaria.

From table 1, there was a correlation between maternal knowledge on malaria and women with malaria disease with $p$-value 0.007 and Odds Ratio (OR) 10. This means that pregnant women with insufficient knowledge of malaria had 10 times higher risk for malaria compared to well-informed pregnant women. Research by Ngambut showed that $86 \%$ of respondents know that malaria is transmitted by mosquito bites. On the impact of untreated malaria, $82.6 \%$ of respondents answered that malaria could kill and $96 \%$ of them know malaria can interfere with work (Ngambut \& Sila, 2013).

Knowledge of pregnant women is closely related to the incidence of malaria. Community's knowledge on malaria alone is not sufficient without behavioral changes to prevent malaria, hence malaria transmission continues. If their knowledge is incorrect, it could lead to false perceptions that is even more difficult to manage. Besides, people also need to know how to prevent or protect themselves and their families from Anopheles bites such as using of mosquito net at bedtime, using mosquito repellants, and installing mosquito wire mesh on windows and ventilations (Suharjo, 2015).

Research conducted by Sukiswo, showed that there was a relationship between knowledge and malaria incidence. Subjects with less knowledge have a 17.5 times greater risk than those with good knowledge. A 
Table 1. Relationship of Risk Factor of Pregnant Woman with Malaria Incidence in Pesawaran District. 2017

\begin{tabular}{|c|c|c|c|c|c|}
\hline \multirow{3}{*}{$\begin{array}{l}\text { Malaria Risk } \\
\text { Factors }\end{array}$} & \multicolumn{4}{|c|}{ Malaria } & \multirow{3}{*}{$\mathrm{p}$-value and $\mathrm{OR}$} \\
\hline & \multicolumn{2}{|c|}{ Not-Patient with Malaria } & \multicolumn{2}{|c|}{ Patient with Malaria } & \\
\hline & $\mathrm{n}$ & $\%$ & $\mathrm{~N}$ & $\%$ & \\
\hline \multicolumn{6}{|l|}{ Knowledge } \\
\hline Good & 109 & $99.1 \%$ & 1 & $0.9 \%$ & \multirow{3}{*}{$\begin{array}{l}\text { p-value }=0.007 \\
\text { OR=10.78 } \\
(1.3-86.6)\end{array}$} \\
\hline $\mathrm{Bad}$ & 91 & $91.0 \%$ & 9 & $9.0 \%$ & \\
\hline Total & 200 & $95.2 \%$ & 10 & $4.8 \%$ & \\
\hline \multicolumn{6}{|l|}{ Behavior } \\
\hline Good & 105 & $99.1 \%$ & 1 & $0.9 \%$ & \multirow{3}{*}{$\begin{array}{l}\mathrm{p} \text {-value }=0.009 \\
\text { OR=9.94 } \\
(1.2-79.9)\end{array}$} \\
\hline Bad & 95 & $91.3 \%$ & 9 & $8.7 \%$ & \\
\hline Total & 200 & $95.2 \%$ & 10 & $4.8 \%$ & \\
\hline \multicolumn{6}{|c|}{ Use of mosquito net } \\
\hline Good & 143 & $97.9 \%$ & 3 & $2.1 \%$ & \multirow{3}{*}{$\begin{array}{l}\mathrm{p} \text {-value }=0.010 \\
\mathrm{OR}=5.85 \\
(1.4-23.4)\end{array}$} \\
\hline Bad & 57 & $89.1 \%$ & 7 & $10.9 \%$ & \\
\hline Total & 200 & $95.2 \%$ & 10 & $4.8 \%$ & \\
\hline \multicolumn{6}{|c|}{ House and Environment Conditions to Prevent Malaria } \\
\hline Good & 84 & $98.8 \%$ & 1 & $1.2 \%$ & \multirow{3}{*}{$\begin{array}{l}\mathrm{p} \text {-value }=0.052 \\
\mathrm{OR}=6.52 \\
(0.8-52.4)\end{array}$} \\
\hline Bad & 116 & $92.8 \%$ & 9 & $7.2 \%$ & \\
\hline Total & 200 & $95.2 \%$ & 10 & $4.8 \%$ & \\
\hline
\end{tabular}

person's behavior is influenced by knowledge. The lack of knowledge has an impact on low public awareness on malaria prevention, such as environmental sanitation (Sukiswo et al., 2014).

Based on research conducted by R.Aisyah, the highest incidence of malaria was among respondents with low education, who tend to have limited knowledge compared to respondents with higher education. Therefore, it is necessary to increase knowledge by conveying information on malaria through electronic and printed media (Aisyah \& Susanna, 2014).

The distribution of public knowledge on these three knowledge variables is relatively good. This is also in accordance with the results of a study conducted by Joseph et al, who concluded that people in Haiti know that malaria is a common problem in the community and knows mosquitoes are vectors of malaria (Keating et al., 2008; Ngambut \& Sila, 2013).

The level of education affects one's knowledge. In general, people with higher educationlevelknow andunderstandmoreabout malaria. Conversely, people with low education level tend to find it difficult to understand about malaria. Malaria incidence was higher among respondents with primary education level. This indicates the low knowledge of the patient about malaria. Education level is often associated with socio-economic conditions. People with good economy condition tend to send their children into college. People with a high education level tend to have better good income, have a permanent home and pay more attention to their family's health. Conversely people with poor economic conditions tend to neglect family education. The low knowledge of respondents also shows difficulty in accessing health information due to lack of information and low awareness of respondents to seek and receive health information. Hence one of the efforts to prevent malaria that is by increasing knowledge on malaria through media 
(Manumpa, 2015).

According to this study, the behavior of pregnant women is related to malaria incidence with p-value of 0.009 and OR 9. This means the risk for malaria is 9 times higher for pregnant women with insufficient malaria prevention behavior compared to pregnant women who practice malaria prevention behaviors well. Community behavior is an individual response to the stimulus from outside or from within him that is active or passive. Individual's overt behaviors, if enhanced and developed, can encourage the growth of public awareness to prevent malaria such as cleaning the yards and ditches, draining stagnant waters around the house, installing mosquito wire mesh, keeping cattle stables at $>100$ meter from the house and using mosquito bed nets. (Suharjo, 2015) Predisposing factors will affect individual's behavior in addressing existing health problems (Ernawati et al., 2011).

Certain behaviors such as outdoor nightly activities, which could include working or leisurely hang-out in and open space, increases the risk for mosquito bites. Anopheles mosquitoes are usually active and feed at night until early morning (ecophagic). This habit becomes more risky if the person does not outfits that covers the entire body or use mosquito repellent before going out of the house. The percentage of nightly outdoor activities was higher in the case group (51.7\%) than the control group (20.7\%), due to increased risk of contact with the mosquitoes (Penggalih et al., 2016).

The use of mosquito net is associated with malaria incidence with $p$-value 0.01 and OR 5.85. This means that pregnant women who did not wear mosquito nets had 5.85 times higher chance of contracting malaria compared with pregnant women who wore mosquito nets. Manumpa also found that respondents who did not use bed nets at night were at higher risk of contracting malaria, $82.8 \%$ in the case group compared to $51.7 \%$ in control group. The results of chi square statistic test found p-value $=0.025$, which means there was a significant relationship between using mosquito nets and malaria incidence. Value of Odds Ratio (OR) $=4.480$ states that respondents who usually do not wear bed nets while sleeping at night are at 4.480 times greater risk of contracting malaria. Insecticide-treated mosquito net is one of malaria prevention strategies in roll back malaria (international malaria prevention movement). However, the use of mosquito net is not effective in Africa. Only one in seven children in Africa sleep with mosquito nets, and only $2 \%$ of children use insecticide treated bed nets (Ernawati et al., 2011).

Respondents who did not use mosquito nets during night sleep are at higher risk of contact with mosquito bites because there was no barrier to approaching mosquitoes during sleep. In principle, the mosquito net serves as a barrier between mosquitoes which contains no holes for mosquito to break thorough, hence effectively avoiding mosquito bites. Job variables, home environmental conditions, and community behavior that include knowledge, attitudes and actions, showed a significant relationship with malaria incidence (Aisyah \& Susanna, 2014).

There was no correlation between house environment condition and malaria incidence, with $\mathrm{p}$-value of 0.052 . House condition is very complex to evaluate, especially mosquitobite protection, which cannot be evaluated in detail. The environment variablewas only measured from general conditions and house environment.

Mardiana found in her study that hills is one of Anopheles mosquitoes' favorite nesting place. The abundance of bushes, barking crops, cardamom, weeds, shrubs, and plantation crops (coffee, cacao, coconut) are good nesting places for Anopheles mosquitoes. Distance from a house to nearby hills affected malaria incidence. The closer the hills from the house, the higher the risk. The ability of mosquito to reach the house was influenced by the type of mosquito, flight and wind speed. Rice fields is another place for malaria mosquitoes' nests. The distance between house and rice field is a risk factor for malaria disease. Forms of human intervention in the processing of agricultural land, for example the pattern of continuous rice cultivation results in maintenance of water puddles, which helps maintain mosquitoes' life cycle. Anopheles aconitus is a malaria vector whose breeding place is in rice fields (Mardiana \& Fibrianto, 2009). The result of multivariate 
Table 2. Multivariate Analysis Results

\begin{tabular}{|c|c|c|c|c|c|c|}
\hline \multirow{2}{*}{ Variable } & & \multirow[b]{2}{*}{ Coefficient } & \multirow[b]{2}{*}{ p-Value } & \multirow[b]{2}{*}{ OR } & \multicolumn{2}{|c|}{ Confidence interval 95\% } \\
\hline & & & & & Lower & Upper \\
\hline \multirow[t]{5}{*}{ First Step } & Knowledge & 2.388 & .029 & 10.89 & 1.27 & 93.38 \\
\hline & Behavior $^{*}$ ) & 1.588 & .159 & 4.90 & 0.54 & 44.66 \\
\hline & Use of Mosquito Net & 1.792 & .025 & 6.00 & 1.26 & 28.61 \\
\hline & $\begin{array}{l}\text { House \& Environment } \\
\text { conditions }\end{array}$ & 2.033 & .071 & 7.64 & 0.84 & 69.29 \\
\hline & Constant & -8.332 & .000 & 0.00 & & \\
\hline \multirow{4}{*}{$\begin{array}{l}\text { Second } \\
\text { Step }\end{array}$} & Knowledge (X1) & 2.353 & .031 & 10.51 & 1.24 & 89.31 \\
\hline & Use of Mosquito Net (X2) & 2.270 & .003 & 9.68 & 2.19 & 42.74 \\
\hline & $\begin{array}{l}\text { House \& Environment } \\
\text { conditions (X3) }\end{array}$ & 2.250 & .043 & 9.49 & 1.07 & 83.95 \\
\hline & Constant & -7.546 & .000 & 0.00 & & \\
\hline
\end{tabular}

${ }^{\star}$ ) removed from the model because the p value is more than 0.05 .

modeling analysis with logistic regression method is shown in the following table 2 .

Out of the 4 risk factors studied, multivariate analysis found 3 major risk factors are correlated with malaria incidence as follows: knowledge, usage of bed nets and housing conditions. As for the model equation with 3 variables of 4 variables examined, by looking at $\mathrm{p}$-value above 0.05 , behavioral variables are removed from the model. The selected model predicted the malaria incidence among pregnant women with regression equation $\mathrm{Y}$ (pregnant woman with malaria) $=-7.546+$ 2.353 (knowledge) +2.270 (usage of mosquito net) +2.250 (condition of house) while the probability of pregnant woman to suffer malaria equal to $33.9 \%$ with the value of $84.3 \%$ equation model (strong).

Multivariate analysis resulted in a fit equation model to predict pregnant woman with malaria incidence of $33.9 \%$ if the risk factor such as knowledge, usage of mosquito net and house environment condition are bad, every 100 pregnant women in this area had 33 pregnant women with malaria.

Prevention of malaria model analysis result found that increasing knowledge is effective, one of which is house spraying. Chemical spraying is less effective because it will kill only adult mosquitoes, while excessive use of insecticides may cause resistance among the mosquitoes or cause respiratory problems among humans. One of the ways to prevent malaria through chemicals used in malaria eradication program in Indonesia is by insecticide treated mosquito net. (Suharjo, 2015) The most important knowledge for prevention is controlling mosquito nests. Protecting pregnant women, infants and toddlers from malaria transmission and promoting increased coverage of routine maternity and immunization services to reduce morbidity and mortality of mothers, infants and toddlers from malaria and P3DI (Program from diseases that can be prevented by immunization) are also important (Muktar, 2007).

Analysis on environmental factors of the house showed that it is closely related to socio-economic condition of the community. Bamboo-walled houses and alang-alang roofs indicates the low socio-economic condition. Socio-economic factors such as poor sanitation, housing, occupations, poverty, etc have an important effect on malaria incidence, especially in developing countries (Ngambut and Sila, 2013).

Suggested strategies in the guidelines of implementation of integrated malaria control activities are: a). Malaria screening in all pregnant women during first pregnancy examination with provision of insecticidetreated mosquito nets and malaria treatment according to malaria case management guidelines; b). Giving insecticide-treated 
bed nets to families with babies after routine immunization; c). Mobilizing the community actively for integrated malaria control activities for pregnancy and immunization-related services (Kementerian Kesehatan RI, 2010).

\section{Conclusion}

Maternalmalariaprevalencein Pesawaran District was 47.6 per mile, distributed in 5 subdistricts, occurred in all endemic districts and 1 non-endemic sub-district. Statistical test for risk factors such as knowledge, behavior and usage of mosquito net showed a significant correlation to malaria incidence, and its reverse on risk factor of condition and environment of pregnant woman's house. However, multivariate analysis of behavior is not included in the predicted maternal pregnancy model.

\section{Acknowledgement}

This research was funded by DIPA Faculty of Medicine, University of Lampung in 2017, the authors also received ample assistance from Health Office employees and Community health centers of Pesawaran District. The authors are very grateful to Mr. Drs. dr. Muhartono, Sp.PA, M.Kes, as the dean of the Faculty of Medicine, University of Lampung and Mr. Abdullah, SKM as the Secretary of the Department of Health for the facilities given and the warm reception. We are deeply indebted for the excellent technical support in the field.

\section{References}

Aisyah, R. A., \& Susanna, D., 2014. Pemakaian Kelambu Berinsektisida pada Anak Usia 0-4 Tahun terhadap Kejadian Malaria. Jurnal Kesehatan Masyarakat Nasional, 9(2), pp. 194-200.

Briand, V., Le Hesran, J. Y., Mayxay, M., Newton, P. N., Bertin, G., Houzé, S., ... Fievet, N. 2016. Prevalence of Malaria in Pregnancy in Southern Laos: A Cross-sectional Survey. Malaria Journal, 15(1), pp. 1-11.

Ernawati, K., Soesilo, B., \& Duarsa, A. 2011. Hubungan Faktor Risiko Individu dan Lingkungan Rumah dengan Malaria di Punduh Pedada Kabupaten Pesawaran Provinsi Lampung Indonesia 2010. Makara Kesehatan, 15(2), pp. 51-7.

Karyana, M., Burdarm, L., Yeung, S., Kenangalem, E., Wariker, N., Maristela, R., ... Price, R. N. 2008. Malaria Morbidity in Papua Indonesia, An Area with Multidrug Resistant Plasmodium vivax and Plasmodium falciparum. Malaria, 10(48), pp. 1-10.

Keating, J., Eisele, T. P., Bennett, A., Johnson, D., \& Macintyre, K., 2008. A Description of Malaria-Related Knowledge, Perceptions, and Practices in the Artibonite Valley of Haiti: Implications for Malaria Control. American Journal of Tropical Medicine and Hygiene, 78(2), pp. 262-9.

Kementerian Kesehatan RI., 2010. Pedoman Pelaksanaan Kegiatan Terpadu Pengendalian Malaria, Pelayanan Ibu Hamil dan Imunisasi. In Malaria. Jakarta.

Kementerian Kesehatan RI., 2016. Pusat Data dan Informasi. In Pusat Data dan Informasi. Jakarta.

Manumpa, S., 2015. Pengaruh Faktor Demografi dan Riwayat Malaria terhadap Kejadian Malaria. Jurnal Berkala Epidemiologi, 4(3), pp. 338-348.

Mardiana., \& Fibrianto, D., 2009. Hubungan Karakteristik Lingkungan Luar Rumah dengan Kejadian Penyakit Malaria. Jurnal Kesehatan Masyarakat, 5(1), pp. 11-6.

Muktar, I., 2007. Kehamilan dan Kejadian Malaria di Puskesmas Way Muli, Lampung Selatan. Jurnal Kesehatan Masyarakat Nasional, 2(1), pp. 19-25.

Ngambut, K., \& Sila, O., 2013. Faktor Lingkungan dan Perilaku Masyarakat tentang Malaria di Kecamatan Kupang Timur Kabupaten Kupang. Jurnal Kesehatan Masyarakat Nasional, 7(6), pp. 271-8.

Penggalih, M. H. S. T., Pratiwi, D., Fitria, F., Sari, M. D. P., Narruti, N. H., Winata, I. N., ... Kusumawati, M. D., 2016. Identifikasi Somatotype, Status Gizi, Dan Dietary Atlet Remaja Stop and Go Sports. Jurnal Kesehatan Masyarakat, 11(2), pp. 222.

Rusjdi, S.R., 2012. Malaria pada Masa Kehamilan. Majalah Kedokteran Andalas, 36(2), pp. 173-8.

Suharjo., 2015. Pengetahuan Sikap dan Perilaku Masyarakat tentang Malaria di Daerah Endemis Kalimantan Selatan. Media Litbangkes, 25(1), pp. 23-32.

Sukiswo, S.S., Rinidar., \& Sugito., 2014. Analisis Risiko Karakteristik, Sosial Ekonomi, Perilaku dan Kondisi Lingkungan Rumah terhadap Kejadian Malaria. Kesehatan Masyarakat Nasional, 9(2), pp. 150-6. 